\title{
Blood mercury levels of dental students and dentists at a dental school
}

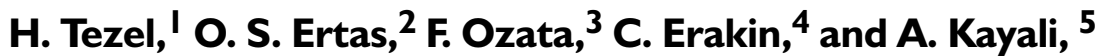

\begin{abstract}
Objective To determine the blood mercury levels in dental students and clinical teaching staff in a dental school using amalgam as a restorative material.

Setting A dental school in Ege University, Turkey surveyed during one academic year.

Subjects and methods Cross-sectional study of groups of dental students $(n=92)$ in years $I$ to $V$, clinical teachers in restorative dentistry $(n=16)$ and controls $(n=14)$. Mercury concentration was estimated in venous blood samples using a cold vapour atomic absorption method at the commencement and end of the academic year. Daily air mercury levels were determined in clinical and teaching areas by measuring the darkening of palladium chloride discs using spectrophotometry. Results There were statistically significant increases $(p<0.001)$ in plasma mercury concentration between measurements in all groups at the end of the academic year. Red cell mercury levels were also consistently elevated. Although the highest levels of mercury were recorded in persons working with amalgam, increased levels were also found in subjects working in the teaching classrooms but not with amalgam (controls and first year students).

Conclusion Increased mercury levels appeared to be due to background exposure from spillage of mercury and amalgam residues on floors. Increased mercury hygiene and regular control of working atmosphere should be implemented to prevent mercury exposure in the dental pre-clinical laboratory.
\end{abstract}

Since the early 18th century, there has been concern about the $S$ possible influence of low-level exposure to mercury, both in the general population and in occupationally exposed groups. ${ }^{1}$

Mercury intake in human beings, excluding occupational exposure, comes mainly from two sources; diet and amalgam restorations. Small amounts of inorganic mercury also enter the body by inhalation, smoking and drinking alcohol. ${ }^{2,3}$

Set silver amalgam consists of 43-50\% mercury, combined with either silver or tin. ${ }^{4}$ Poor mercury hygiene within the working environment due to incorrect storage or spillage of mercury or waste amalgam, preparation of amalgam, placement and removal of amalgam restorations, and polishing of amalgam restorations ${ }^{5}$ result in dental professionals' exposure to mercury vapour. ${ }^{6}$

${ }^{1}$ Assistant Professor, Department of Restorative Dentistry and Endodontics,

Faculty of Dentistry, Ege University, Bornova Izmir-Turkey; ${ }^{2 *}$ Assistant Professor, Department of Analytical Chemistry, Faculty of Pharmacy, Ege University, Bornova Izmir-Turkey: ${ }^{3}$ Professor, Department of Restorative Dentistry and Endodontics, Faculty of Dentistry; ${ }^{4}$ Department of Restorative Dentistry and Endodontics, Faculty of Dentistry; ${ }^{5}$ Professor, Department of Analytical Chemistry, Faculty of Pharmacy

${ }^{*}$ Correspondence to: Ozlem Sogut Ertas

email:soguto@alpha.pharm.ege.edu.tr

REFEREED PAPER

Received 7.01.00; Accepted 31.05.01

(c) British Dental Journal 2001; 191: 449-452
The release of mercury vapour from intraoral amalgam restorations has been detected in the course of amalgam placement and removal, during chewing, polishing and surface abrasion and corrosion of restorations. ${ }^{7,8,9,10,11}$ Corbin and Kohn ${ }^{12}$ state that many researchers have found that mercury vapour released from amalgam restorations varies from $1.24-27 \mu \mathrm{g} /$ day. While most of the researchers agree that current evidence does not demonstrate that amalgam restorations are hazardous to the health of the general population, some report that mercury release from amalgam is one of the important sources of inorganic mercury.

Interest in the possible toxicity of mercury in dentistry has resulted in a rapidly increasing number of articles. ${ }^{13}$ According to recent studies, blood mercury levels of dentists are twice as high as in normal individuals. ${ }^{5}$ Even though there is a widespread belief that only the patients are affected by mercury in amalgam fillings; dentists, dental staff and students may be those actually affected. Therefore the aim of this study was to determine the blood mercury levels of dental students and faculty dentists.

\section{Materials and Methods}

Dental students from the first year to the fifth, and the clinical teachers at the department of restorative dentistry of Ege University who are being exposed to amalgam more than those in other departments were examined. While determining the individuals for the experimental groups, their alcohol and cigarette consumption and eating habits (sea products) were taken into consideration. Individuals who had similar food consumption habits and did not consume sea products, as well as alcohol or cigarette were selected to minimise the deviations that might result from diets. A total of $90 \%$ of the experimental and the control group had never consumed sea products. The rest had them once or twice a month in their diet. No amalgam restorations were made in these individuals during the study.

The control group was composed of 14 clinical teachers who worked in the department of periodontology full time and never worked with amalgam but sometimes shared clinical areas. The controls were selected to be similar to the exposed group in terms of working conditions, alcohol and cigarette consumption and dietary habits.

The dental school was built in 1968. Every year 100 new students come to the faculty from different parts of Turkey. The academic year starts in September and ends in July. Although there is a threeweek semester break between the terms, final and re-sit examinations are held during this period.

The study groups worked in 4 different clinics and the phantomhead laboratory. The 1st year students work in the laboratory only to improve their manipulative skills. In the 2 nd year, they begin their pre-clinical 'phantom head' course which continues for 2 years. For the first three years, students work in the same laboratory where the phantom-head course is based, but only the 2nd and the 3rd year students work with mercury. The background of the groups and the usage of the clinics are shown in Table 1. 


\section{RESEARCH occupational health}

Table I. The distribution of I 22 individuals according to study groups.

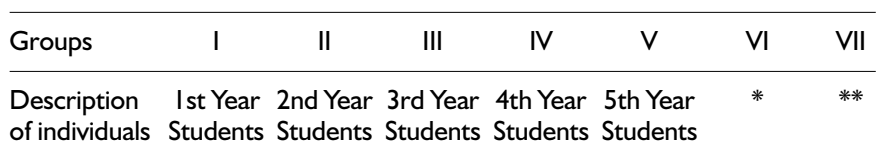

of individuals Students Students Students Students Students

\section{Number}

* The clinical teachers working in the department of restorative dentistry at the faculty

** Control group

Working conditions in the clinics and the laboratory were recorded regarding the average area of clinics, type of ventilation, type of floor covering and type of amalgam mixer (Table 2). The annual average of daily air mercury levels during the period of the work in the student laboratory, Clinic 1, Clinic 2, Clinic 3, Clinic 4 were $0.027 \mathrm{mg} / \mathrm{m}^{3}$, $0.025 \mathrm{mg} / \mathrm{m}^{3}, 0.025 \mathrm{mg} / \mathrm{m}^{3}, 0.048 \mathrm{mg} / \mathrm{m}^{3}$ and $0.008 \mathrm{mg} / \mathrm{m}^{3}$ respectively. The vapour concentration of mercury was measured by using $\mathrm{PdCl}_{2}$ discs. ${ }^{14,15}$ The darkening of the test papers was evaluated with a spectrophotometer. The average concentrations were derived from the results of numerous measurements carried out throughout the academic year.

\section{Table 2. Background facts about the clinics}

\begin{tabular}{|c|c|c|c|c|c|c|c|}
\hline Places & $\begin{array}{c}\text { Room } \\
\text { Area } \\
\mathrm{m}^{2}\end{array}$ & $\begin{array}{c}\text { Floor } \\
\text { Covering } \\
\text { (type) }\end{array}$ & $\begin{array}{c}\text { Amalgam } \\
\mathrm{g} \quad \begin{array}{l}\text { Mixer } \\
\text { (type) }\end{array}\end{array}$ & $\begin{array}{c}\text { Ventilation } \\
\text { (type ) }\end{array}$ & $\begin{array}{l}\text { Daily } \\
\text { Cleaning } \\
\text { Habits }\end{array}$ & $\begin{array}{l}\text { Groups } \\
\text { working in } \\
\text { the room }\end{array}$ & $\begin{array}{c}\text { Groups } \\
\text { who work } \\
\text { with } \mathrm{Hg}\end{array}$ \\
\hline $\begin{array}{l}\text { Student } \\
\text { Laborator }\end{array}$ & 275 & Terrazzo & Amalgam* & $\begin{array}{l}\text { Passive+ } \\
\text { Mechanic }\end{array}$ & $\begin{array}{c}\text { Wet } \\
\text { cleaning }\end{array}$ & I, 2, 3 & 2,3 \\
\hline Clinic I & 308 & Terrazzo & Mixer*⿻丷木 & Passive & $\begin{array}{l}\text { Wet } \\
\text { cleaning }\end{array}$ & 4 & 4 \\
\hline Clinic 2 & 210 & $\begin{array}{l}\text { Porcelain } \\
\text { tile }\end{array}$ & Mixer*** & $\begin{array}{l}\text { Passive+ } \\
\text { Mechanic }\end{array}$ & $\begin{array}{l}\text { Vacuum } \\
\text { cleaning }\end{array}$ & 5 & 5 \\
\hline Clinic 3 & 110 & $\begin{array}{l}\text { Mosaic } \\
\text { tile }\end{array}$ & Mixer*** & $\begin{array}{l}\text { Passive+ } \\
\text { Mechanic }\end{array}$ & $\begin{array}{l}\text { Vacuum } \\
\text { cleaning }\end{array}$ & 6 & 6 \\
\hline Clinic 4 & 110 & $\begin{array}{c}\text { Mosaic } \\
\text { tile }\end{array}$ & $\begin{array}{c}\text { Mixer*** } \\
\text { Capsules** }\end{array}$ & $\begin{array}{c}\text { Passive+ } \\
\text { *Mechanic }\end{array}$ & $\begin{array}{l}\text { Vacuum } \\
\text { cleaning }\end{array}$ & Control & - \\
\hline $\begin{array}{l}\text { ** The D } \\
\text { ** Vari-n }\end{array}$ & mix & $\begin{array}{l}3 \text { is } \\
\text { entsp }\end{array}$ & $\begin{array}{l}\text { ly } \\
\text { ing an }\end{array}$ & $\ldots$ & & & \\
\hline
\end{tabular}

Blood was collected from the vena saphalior in metal-free polyethylene tubes. The blood samples were centrifuged at $1500 \mathrm{~g}$ for $20 \mathrm{~min}-$ utes at $5^{\circ} \mathrm{C}$. Packed erythrocytes and plasma were then separated by means of a serum separator. All the samples were stored at $-20^{\circ} \mathrm{C}$ until analysed within 4 months.

The samples were wet digested with nitric acids and perchloric acids $(5: 1)$ at $25-35^{\circ} \mathrm{C}$. Then the samples, filtered through Whatman Ashless Filter Paper $90 \mathrm{~mm} \emptyset$, were added to bidistilled water to the total amount of $10 \mathrm{~mL}^{16}$

The mercury content was determined in wet-digested samples by a 'cold vapour' atomic absorption technique using mercury evaporation kit (Varian 4S) at Varian 10plus AA. All chemicals used in the analysis were in the analytical grade. ${ }^{17,18,19}$

To ascertain the accuracy of the method pre-determined amounts of $\mathrm{Hg}^{+2}$ in $\mathrm{HNO}_{3}$ were added to other blood plasma samples to roughly double the original mercury concentration. The results indicated that our method was highly reliable. Every sample was analysed in triplicate and the variation between three runs was low $(\mathrm{CV}<10 \%)$. Also the variations of daily analyses for the same samples were also low $(\mathrm{CV}<10 \%)$. These meant that the precision and the reproducibility of the method were high. Other analytical validation para- meters including sensitivity and ruggedness were checked, and certified that the method was acceptable for the analysIs. ${ }^{20}$

The measurements were estimated in $\mu \mathrm{g} / \mathrm{L}$ and expressed by means of total mercury in blood, considering the plasma and erythrocyte ratio $(2 / 3) .{ }^{21}$ The data at the beginning and at the end of the academic year were evaluated and the differences between the groups were statistically analysed.

Statistical analysis of the results was performed using paired $t$-test at the significance level of $\alpha=0.05$.

\section{Results}

Frequency and duration of amalgam work were different for all groups. For the second and the third group, the average weekly active amalgam work period was eight hours. The first group worked in the same laboratory within the same time period nearly six hours per week. The fourth and fifth groups worked with amalgam for twenty-five hours per week during a five-week period. For the sixth group, the average weekly working time was ten hours. The temperature for all the rooms varied between $21^{\circ} \mathrm{C}$ and $24^{\circ} \mathrm{C}$ and the relative air humidity was between 14 and $39 \%$.

The mercury vapour concentrations in the air for the student laboratory and the clinics $1,2,3,4$ were $27,25,25,48$ and $8 \mu \mathrm{g} / \mathrm{cm}^{3}$ respectively.

When groups were analysed separately, the increase of mercury concentration in the blood and plasma measured at the beginning and at the end of the academic year was statistically significant for each group $(\mathrm{p}<0.001)$. The statistical analysis of the groups is shown in Table 3. The highest increases were in the fourth, fifth and third group respectively. The smallest were in the first and in the control group (Figure 1,2).

\section{Discussion}

Exposure to metallic mercury vapour within the confines of the dental office is the major source of high blood concentrations of inorganic mercury in dentists. About $80 \%$ of inhaled mercury will rapidly cross the pulmonary membranes and dissolve in the circulating blood. ${ }^{22}$ This circulating mercury is partitioned between packed cells and plasma. ${ }^{23}$

Improvement of technical equipment and better standards of hygiene, however, can reduce exposure significantly. The way in which amalgam is prepared, cleaning habits, and types of floor coverings have been pointed out to be important factors. ${ }^{24}$

In this study the blood results were obtained by considering the plasma and erythrocyte ratio $(2 / 3) .{ }^{19}$ The study demonstrated that the increase of total mercury in plasma and blood was significant in groups IV, V, and particularly in the teaching staff (Group VI) who worked with amalgam. The total mercury levels reached in these groups were approximately $52.09,49.71$ and $52.13 \mu \mathrm{g} / \mathrm{L}$ in plasma and $32.41,31.72$ and $45.02 \mu \mathrm{g} / \mathrm{L}$ in blood respectively. The plasma levels of these groups were higher than TLV $(50 \mu \mathrm{g} / \mathrm{L}),{ }^{25}$ whilst the blood levels were lower than TLV values. The increase was found to be quite substantial in the 2nd year of study, which is the year students use amalgam for the first time, but thereafter the levels in succeeding years remained relatively steady. It is curious that all groups demonstrated lower levels at the beginning of the academic year than at the end. It would seem that the summer holiday was beneficial in ridding the body of mercury.

The location of the dental school is advantageous for this study in that it is a mercury-free area being in a university campus out of the city and far from the industrial areas. Atmospheric pollution can therefore be discounted as a factor. In this study, Group 1 and the Control Group included individuals who did not work with amalgam. In the first group at the beginning of the term, values were found to be almost $14.00 \mu \mathrm{g} / \mathrm{L}$ in plasma and $10.78 \mu \mathrm{g} / \mathrm{L}$ total mercury level in blood. These values subsequently increased to 34.01 $\mu \mathrm{g} / \mathrm{L}$ and $24.19 \mu \mathrm{g} / \mathrm{L}$ respectively. In group 7 (the control group) at 
Table 3: Statistical evaluation within the groups.

\begin{tabular}{|c|c|c|c|c|c|c|c|c|}
\hline Group & $\mathrm{n}$ & Samples & Mean & Median & Range & $\begin{array}{l}\text { Standard } \\
\text { deviation }\end{array}$ & $\begin{array}{l}\text { Coefficient } \\
\text { of variation }\end{array}$ & P-Value \\
\hline \multirow[t]{4}{*}{ I. } & 28 & Plasma & $13.99 \mathrm{a}$ & $12.32 \mathrm{a}$ & $31.79 a$ & $7.25 a$ & $51.81 \mathrm{a}$ & 0.010 \\
\hline & & & $34.0 \mathrm{Ib}$ & $29.30 \mathrm{~b}$ & $102.10 \mathrm{~b}$ & $32.62 \mathrm{~b}$ & $95.93 \mathrm{~b}$ & \\
\hline & & Blood & $10.78 \mathrm{a}$ & $9.72 \mathrm{la}$ & $23.59 a$ & $5.36 \mathrm{a}$ & $49.68 \mathrm{a}$ & 0.005 \\
\hline & & & $24.19 b$ & $22.57 \mathrm{~b}$ & $65.64 \mathrm{~b}$ & $20.26 \mathrm{~b}$ & $83.77 \mathrm{~b}$ & \\
\hline \multirow[t]{4}{*}{ II. } & 17 & Plasma & $17.78 \mathrm{a}$ & $12.88 \mathrm{a}$ & $109.42 \mathrm{a}$ & $24.47 a$ & $137.64 a$ & 0.000 \\
\hline & & & $49.68 \mathrm{~b}$ & $46.50 \mathrm{~b}$ & $103.24 \mathrm{~b}$ & $28.5 \mathrm{Ib}$ & $57.38 \mathrm{~b}$ & \\
\hline & & Blood & $10.07 a$ & $9.78 \mathrm{a}$ & $14.09 a$ & $3.50 \mathrm{a}$ & $34.7 \mathrm{la}$ & 0.001 \\
\hline & & & $33.4 \mathrm{lb}$ & $34.64 \mathrm{~b}$ & $76.53 \mathrm{~b}$ & $19.48 \mathrm{~b}$ & $58.3 \mathrm{lb}$ & \\
\hline \multirow[t]{4}{*}{ III. } & 15 & Plasma & $11.02 a$ & $10.00 \mathrm{a}$ & $15.33 \mathrm{a}$ & $4.34 \mathrm{a}$ & $39.35 a$ & 0.014 \\
\hline & & & $45.35 \mathrm{~b}$ & $31.60 \mathrm{~b}$ & $125.00 \mathrm{~b}$ & $41.95 b$ & $92.50 \mathrm{~b}$ & \\
\hline & & Blood & $11.57 \mathrm{a}$ & $8.68 \mathrm{a}$ & $32.03 a$ & $7.92 \mathrm{a}$ & $68.4 \mathrm{la}$ & 0.012 \\
\hline & & & $29.44 b$ & $18.96 \mathrm{~b}$ & $77.4 \mathrm{Ib}$ & $24.43 b$ & $84.89 \mathrm{~b}$ & \\
\hline \multirow[t]{4}{*}{ IV. } & 19 & Plasma & $10.20 \mathrm{a}$ & $10.02 a$ & $13.39 a$ & $3.15 \mathrm{a}$ & $30.88 \mathrm{a}$ & 0.000 \\
\hline & & & $52.09 b$ & $52.23 \mathrm{~b}$ & $1 / 8.72 b$ & $30.27 b$ & $58.1 \mathrm{lb}$ & \\
\hline & & Blood & $8.729 a$ & $7.48 \mathrm{a}$ & $11.17 a$ & $2.87 \mathrm{a}$ & $32.90 \mathrm{a}$ & 0.000 \\
\hline & & & $32.4 \mathrm{lb}$ & $31.34 \mathrm{~b}$ & $72.6 \mathrm{lb}$ & $18.82 \mathrm{~b}$ & $58.07 \mathrm{~b}$ & \\
\hline \multirow[t]{4}{*}{ V. } & 13 & Plasma & $10.74 a$ & $10.77 \mathrm{a}$ & $6.96 \mathrm{a}$ & $2.17 \mathrm{a}$ & $20.21 \mathrm{a}$ & 0.002 \\
\hline & & & $49.7 \mathrm{Ib}$ & $55.10 \mathrm{~b}$ & $84.90 \mathrm{~b}$ & $26.45 b$ & $53.60 \mathrm{~b}$ & \\
\hline & & Blood & $9.4 \mathrm{Ia}$ & $8.36 \mathrm{a}$ & $8.84 a$ & $2.38 \mathrm{a}$ & $25.27 \mathrm{a}$ & 0.003 \\
\hline & & & $31.72 \mathrm{~b}$ & $36.33 \mathrm{~b}$ & $50.94 b$ & $17.2 \mathrm{lb}$ & $54.25 b$ & \\
\hline \multirow[t]{4}{*}{ VI } & 16 & Plasma & $10.87 a$ & $10.77 \mathrm{a}$ & $23.99 a$ & $5.38 \mathrm{a}$ & $49.48 \mathrm{a}$ & 0.008 \\
\hline & & & $52.13 \mathrm{~b}$ & $44.06 \mathrm{~b}$ & $151.39 \mathrm{~b}$ & $52.1 \mathrm{~b}$ & $99.94 \mathrm{~b}$ & \\
\hline & & Blood & $15.69 \mathrm{a}$ & $9.26 \mathrm{a}$ & $81.69 a$ & $19.63 a$ & $128.14 a$ & 0.021 \\
\hline & & & $45.02 \mathrm{~b}$ & $34.9 \mathrm{lb}$ & $22.45 b$ & $56.77 \mathrm{~b}$ & $126.09 \mathrm{~b}$ & \\
\hline \multirow[t]{4}{*}{ VII. } & 14 & Plasma & $11.24 a$ & $11.70 a$ & $13.66 \mathrm{a}$ & $4.13 a$ & $36.72 \mathrm{a}$ & 0.012 \\
\hline & & & $32.77 \mathrm{~b}$ & $33.60 \mathrm{~b}$ & $69.43 \mathrm{~b}$ & $26.69 b$ & $81.44 b$ & \\
\hline & & Blood & $9.03 a$ & $8.64 a$ & $8.86 a$ & $2.46 a$ & $27.26 a$ & 0.012 \\
\hline & & & $22.25 \mathrm{~b}$ & $28.07 \mathrm{~b}$ & $41.66 \mathrm{~b}$ & $16.46 \mathrm{~b}$ & $73.98 \mathrm{~b}$ & \\
\hline
\end{tabular}

a. Measurements at the beginning of the academic year $(\mu \mathrm{g} / \mathrm{L}) \quad$ b. Measurements at the end of the academic year $(\mu \mathrm{g} / \mathrm{L})$

the beginning of the study, total mercury level values were 11.24 $\mu \mathrm{g} / \mathrm{L}$ in plasma and $9.03 \mu \mathrm{g} / \mathrm{L}$ in blood. These values subsequently increased to $32.77 \mu \mathrm{g} / \mathrm{L}$ and $22.25 \mu \mathrm{g} / \mathrm{L}$. In both plasma and blood, mercury levels of these groups were below $50 \mu \mathrm{g} / \mathrm{L} .{ }^{25}$ Thus total mercury levels of blood and plasma increased significantly not only in dental teachers who did not work with amalgam but also in the first year students. This latter increase may be due to the common use of the preclinical laboratories by other groups who did work with amalgam.

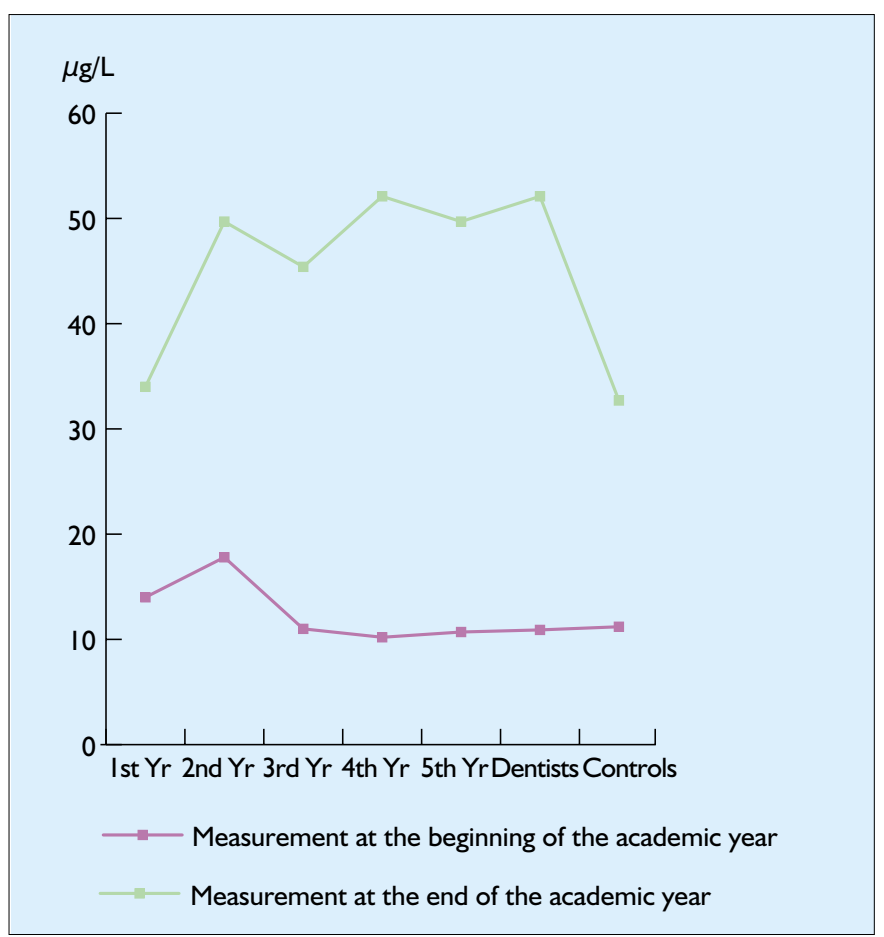

Figure I. Mercury concentration in plasma
It is curious that at the beginning of the academic year, the first year students showed higher plasma levels than the control group. These students, having had no previous exposure to dental amalgam, could be adjudged to exhibit values that might be expected to be found in the general population of Turkey. It is also curious that the second year students exhibited the highest plasma levels of all those in the study at the beginning of the academic year, as shown in Figure 3. The dentists on the other hand showed highest levels of mercury in blood (Fig. 4) (although not in plasma) and this could

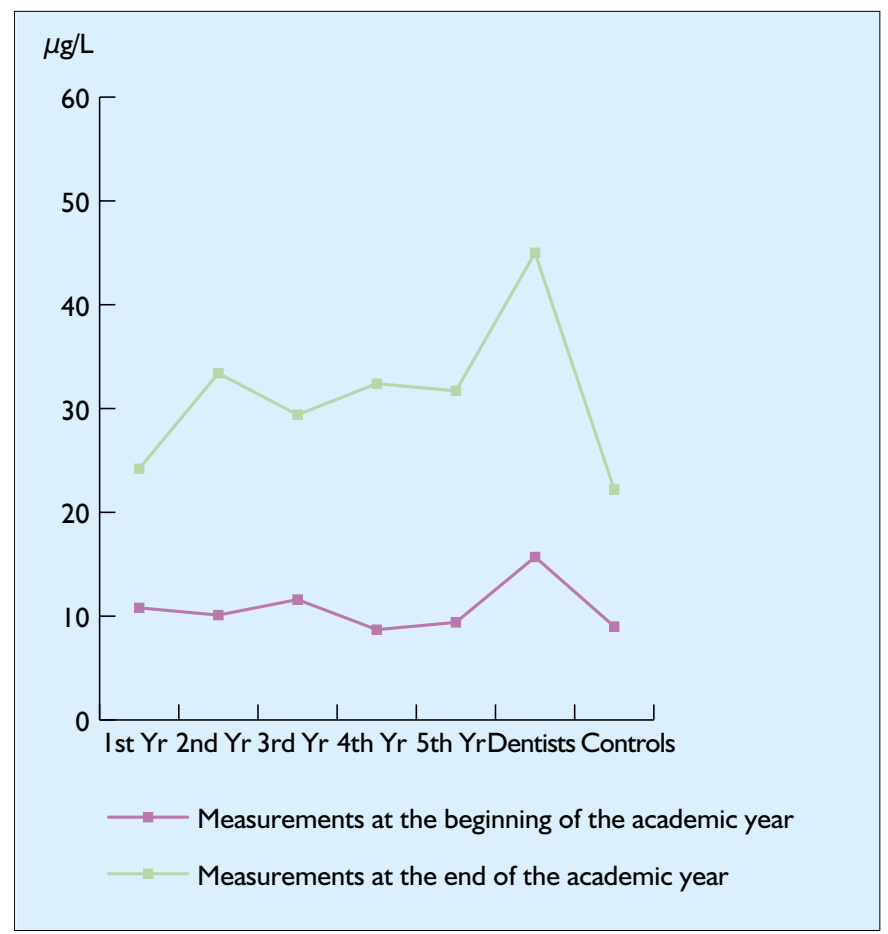

Figure 2. Mercury concentration in blood cells 


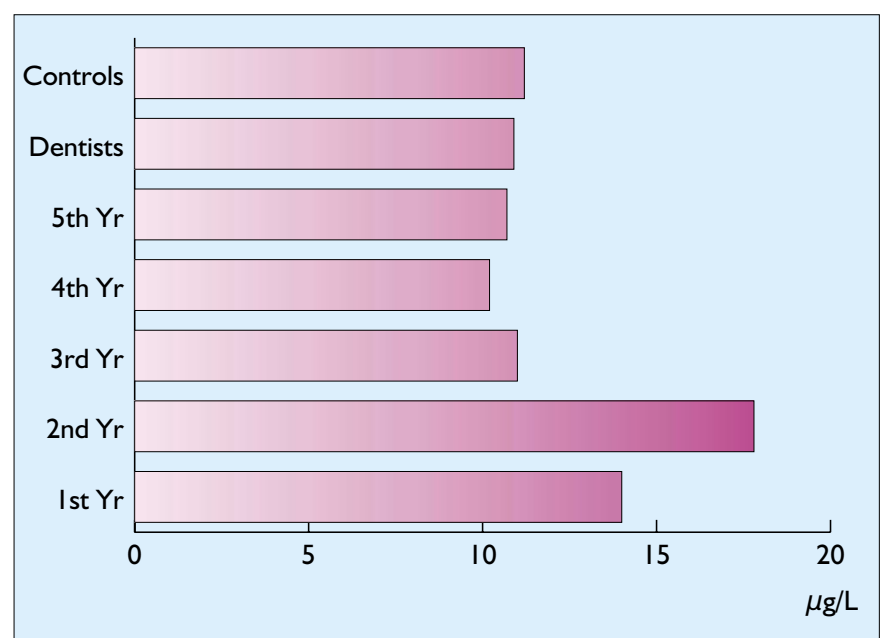

Figure 3. Baseline values for plasma

point to an increased body burden accrued over their practising career.

Berglund ${ }^{26}$ states that the daily dose of inhaled mercury in a work environment where the mercury vapour levels exceeds the then TLV of $50 \mu \mathrm{g} / \mathrm{m}^{3}$ will be 300-500 $\mu$ gs per day, depending on the degree of physical activity and the respiratory minute volume during the work concerned. In this study the levels of mercury vapour in the various rooms were, with the exception of clinic 4 , in excess of current WHO recommended industrial threshold of $25 \mu \mathrm{g} / \mathrm{m}^{3}$ air. Those working in these rooms were shown to have raised levels of plasma and blood levels of mercury at the end of the study compared with the control group who worked in a 'cleaner' environment.

In this study, other sources of mercury had been excluded in the selection of participants. This included provision of dental amalgam restorations to the members of the study groups. Elemental mercury evaporation from any existing amalgam restorations would make only a small contribution to the total body burden of mercury, certainly in the comparison to what can be tolerated in dental clinics for eight hours a day, five days a week for a whole working life. The results of our study show that dental students and clinical teachers are at risk.

Increase in total mercury concentrations in plasma and whole blood depends on mercury hygiene and amalgam practise. Nilsson \& Nilsson ${ }^{27}$ showed that amalgam-practising style was very important even if dentists were ultra careful about mercury hygiene. The British Dental Association's (BDA) guidelines were published in 1993 regarding staff training, personal hygiene, operating procedures, management of waste mercury and amalgam, and the disposal of mercury contaminated waste and materials. It described the procedures to deal with mercury spillage and the need for routine monitoring for mercury exposure. ${ }^{5}$ With this in mind, we have given more attention to mercury hygiene; students' laboratories and clinics are now being ventilated at all times and all the waste products are sent to a city incinerator 25 kilometres away from the building.

\section{Conclusion}

This study showed that dentists and dental students are affected by mercury vapour existing in their clinics and laboratories. Considering these findings we conclude that close attention should be given to mercury hygiene in laboratories and clinics including good ventilation, control of waste mercury chains and enhanced care in handling.

Acknowledgement goes to Eoin Smart for his help in preparing this document for publication.

1 Brune D, Nordberg G F, Vesterberg O, Gerhardsson L, Wester P O. A review of normal concentrations of mercury in human blood. Sci Total Environ 1991; 100: 235-282.

2 Brown L J. Dental amalgam. Designs for research in human populations.

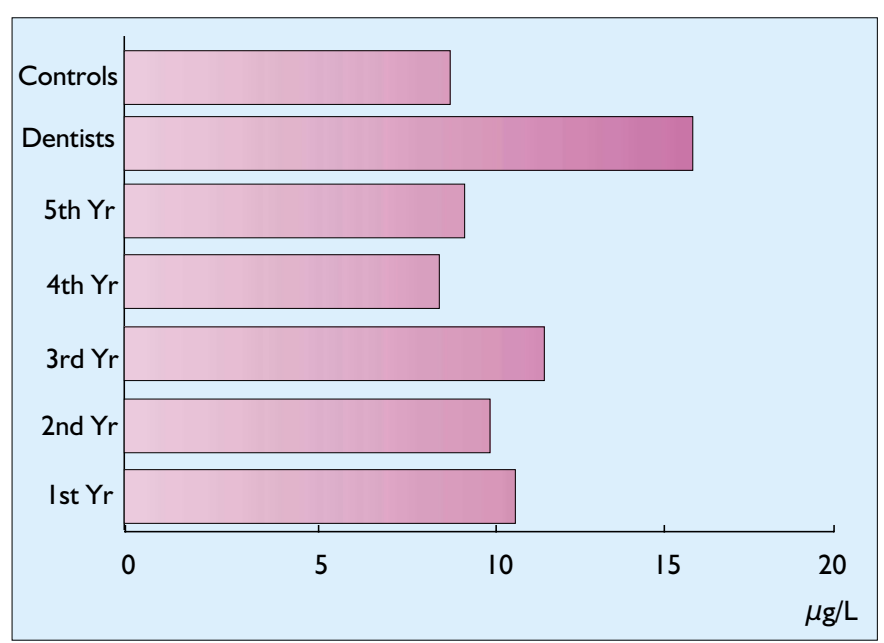

Figure 4. Baseline values for blood

J Am Dent Assoc 1991; 122: 73-77.

3 Clarkson T W. Mercury. J Am Coll Toxicol 1989; 8: 1291-1295.

4 McGroddy S, Chapman P. Mercury from amalgam. Environ Toxicol Chem 1997; 16: 2213-2214.

5 Fung Y F, Molvar M P. Toxicity of mercury from dental environment and from amalgam restorations. J Toxicol Clin Toxicol 1992; 30: 49-61.

6 Eley B M. The future of dental amalgam: a review of the literature Part 2: mercury exposure in dental practice. Br Dent J 1997; 182: 293-297.

7 Chang S B, Siew C, Gruninger S E. Factors affecting blood mercury concentrations in practicing dentists. J Dent Res 1992; 71: 66-74.

8 Forsten L. Blood mercury content after chewing. Acta Odontol Scand 1989; 47: 127-128.

9 Mackert J R. Dental amalgam and mercury. J Am Dent Assoc 1991; 122: 54-61.

10 Marek M. Interactions between dental amalgams and oral environment. Adv Dent Res 1992; 6: 100-109.

11 Osborne J W. Dental amalgam and mercury vapor release. Adv Dent Res 1992; 6: 135-138.

12 Corbin S B, Kohn W G. The benefits and risks of dental amalgam: current findings reviewed. J Am Dent Assoc 1994; 125: 381-388.

13 Eley B M, Cox S W. The release, absorption and possible health effects of mercury from dental amalgam: a review of recent findings. Br Dent J 1993; 175: $161-168$ and 355-362.

14 Jorgensen K D. A semi-quantitative test for mercury in air. Acta Odontol Scand 1974; 32: 305-308.

15 Brown D. Detection of mercury vapor in dental surgery. An assessment of disposable monitoring discs. Br Dent J 1983; 155: 237-240.

16 Bernhard M. Manual of methods in aquatic environment research. Part 3 Sampling and analyses of biological material. Fisheries technical paper number 158. Rome: FAO Fisheries Technical Papers (FAO).

17 Molin M, Bergman B, Marklund S L, Schutz A, Skerfving S. The influence of dental amalgam placement on mercury, selenium and glutathione peroxidase in man. Acta Odontol Scand 1990; 48: 287-295.

18 Snapp K R, Boyer D B, Peterson L C, Svare C W. The contribution of dental amalgam to mercury in blood. J Dent Res 1989; 68: 780-785.

19 Vesterberg O. Automatic method for quantitation of mercury in blood, plasma and urine. J Biochem Biophys Methods 1991; 23: 222-235.

20 Ertas S O. An attempt to determine analytical validation parameters for flame atomic absorption spectrophotometry. PhD. Thesis, 1995.

21 Guyton A C. Textbook of Medical Physiology p 207. 7th ed. Philadelphia: W.B. Saunders Co., 1986

22 Clarkson T W. Quantitative measures of the toxicity of mercury in man. In Prasad A S (ed). Trace elements in human healthy and disease. Volume 2 Essential and Toxic elements. pp 453-475. New York: Academic Press, 1976.

23 Cherian M G, Hursh J B, Clarkson T W, Allen J. Radioactive mercury distribution in biological fluids and excretion in human subjects after inhalation of mercury vapor. Arch Environ Health 1978; 33: 109-114.

24 Langworth S. Exposure to mercury vapor and impact on health in the dental profession in Sweden. J Dent Res 1997; 76: 1397-1404.

25 Vesterberg O. Automatic method for quantitation of mercury in blood, plasma and urine. J Biochem Biophys Methods 1991; 23: 227-235.

26 Berglund A. Estimation by a 24-hour study of the daily dose of intra-oral mercury vapor inhaled after release from dental amalgam. J Dent Res 1990; 69: 1646-1651.

27 Nilsson B, Nilsson B. Mercury in dental practise. I. The working environment of dental personnel and their exposure to mercury vapour. Swed Dent J 1986; 10: 1-14. 